\title{
Resident's Perception Towards Environmental Impact on Human Wellbeing Near the Quarry Mining Vicinity
}

\author{
Wan Hasmirah Wan Ibrahim ${ }^{1, *}$, Emma Marinie Ahmad Zawawi ${ }^{1}$, Khalida Mohd Sukur ${ }^{1}$, Julitta Yunus $^{1}$ and Norfashiha \\ Hashim $^{1}$ \\ ${ }^{1}$ Faculty of Architecture, Planning and Surveying, Universiti Teknologi MARA, 40150 Selangor, Malaysia
}

\begin{abstract}
This study investigates the life quality of residents near the quarry mining vicinity. There are still large population found stayed within this area. The negative impact of quarry mining activities such as health problem and air pollution are among the variables that influence the human well being. The objective of this study is to investigate the experience from the residents towards the quality of air near their residential and to provide a suitable preventive measure in order to reduce this air pollutant issue. A set of questionnaire was distributed to the community at Bandar Saujana Putra and Taman Kajang Perdana, in Selangor. Residents were randomly selected to participate in this study. The study reveals the community's problem related to health condition and safety. It is anticipated that this study could assist the residence and authorities in improving the quality of air in this area by providing the suitable preventive measure.
\end{abstract}

\section{Introduction}

Quarry industry is among the important industries in the development of a country. For the economic development purposes, the quarry industry needs to continue the supply of the raw materials to the construction, building and manufacturing. However, to sustain in the development, both industry and the government agencies needs must take the responsibility to control its activities. The increasing of the population may result to raise the number of residents. Besides, limitation of land is always been an issued and it is a very high potential that where residential will be developed near the quarry mining [1]. This scenario eventually may worsen the level of Air Quality Index (AQI), where the dust from quarry sites being a major source of air pollution. According to [2], the steadiness between the environment and economic development need to improve, the legislation needs to create the improvement of the quarry on management and provide preventive measures for preserving the environment. Section 34A in Environmental Quality Act, 1974 Amendment 1985 requires Environmental Impact Assessment (EIA) report must contain an assessment, prevention and reducing the impact on the environment [3]. According to [4-5], from 49 Environmental Impact Assessment (EIA), reports studied starting from 1995 to 2002 on housing construction activity that proposed with quarry or any industry, the buffer must be at least three (3) kilometres away from quarry site. However, due to the growth of population, a lot of housing built near the industrial area. From that there were many negative impacts due to the quarry mining will be issued such as cracks in houses, broken roads, dirt and dust in the atmosphere, and noise from blasting. Undeniable, today population grew rapidly and led to many residential to be built near the quarry [1].

The purpose of conducting this research is to investigate the experience from the resident towards the quality of air near their residences and to prepare a preventive measure for them in facing quarry mining activities. In the past, the growth of development was not an issue due to most quarry mining were far away from residential and the people. Time passing by, the growth of the population rapidly increased and expanded the number of housing pushed to be built near the quarries [7]. Hence, the aim of this study is to identify the resident's perception of air quality near their residential area.

\section{Methodology}

\subsection{Captions/numbering}

This study used a random sampling technique. Two case studies were selected by perimeter ranged 1 kilometre from the quarry mining to the residential area. A set of questionnaires were distributed to the selected residences to investigate the issues and effects towards them from that quarry activities. The questionnaire was structured into three (3) sections which are background information, the impact of quarry activities on the residential area and preventive measures. There were 60 numbers of the resident from two locations in Selangor involved in this survey. Table 1 shows the list of the location of selected communities to distribute the questionnaire.

* Corresponding author: author@e-e-mail.org 
Table 1. The location for Distribute Questionnaire.

\begin{tabular}{|l|c|l|}
\hline Selected Location & $\begin{array}{l}\text { No of } \\
\text { Respondents }\end{array}$ & $\begin{array}{l}\text { Distance } \\
\text { from } \\
\text { Quarry to } \\
\text { Residential } \\
\text { Area }\end{array}$ \\
\hline Bandar Saujana Putra & \multirow{2}{*}{60} & $\begin{array}{c}200 \mathrm{~m} \\
400 \mathrm{~m} \\
600 \mathrm{~m} \\
800 \mathrm{~m} \\
1000 \mathrm{~m}\end{array}$ \\
\hline Taman Kajang Perdana & & 1 kilometre \\
\hline Total & 60 & \\
\hline
\end{tabular}

Questions were asked on the impact of quarrying to resident, perceptions' about quarrying activities, resident's health experiences and mitigation plan to overcome the problems. Due to the nature of quantitative research, the data was collected until the saturation point is achieved. Cases for this study were selected from residents at Bandar Saujana Putra and Taman Kajang Perdana in Selangor within 1 kilometre $(\mathrm{km})$ perimeter radius of the quarry mining to the residential area.

\section{Finding}

All data collection were analysed using Microsoft Excel version 2010 and the finding are discussed below:

Table 2. Distance of quarry mining area to the residential area.

\begin{tabular}{|c|c|c|}
\hline $\begin{array}{c}\text { Distance } \\
(\mathbf{m})\end{array}$ & No of Respondent & Percentage (\%) \\
\hline$<200$ & 14 & $23.33 \%$ \\
\hline$<400$ & 10 & $16.67 \%$ \\
\hline$<600$ & 8 & $13.33 \%$ \\
\hline$<800$ & 7 & $11.67 \%$ \\
\hline$>1000$ & 21 & $35 \%$ \\
\hline Total & 60 & $100 \%$ \\
\hline
\end{tabular}

Table 2 shows there are 60 numbers of residents participated in this study. As mention in section 2.1, the samplings were randomly picked with a distance of 200 meters each. Majority of respondents are housewife and elderly people. They spent most of the daytime at home.

Table 3. Surrounding Temperature

\begin{tabular}{|c|c|c|}
\hline $\begin{array}{c}\text { Surrounding } \\
\text { Temperature }\end{array}$ & $\begin{array}{c}\text { No of } \\
\text { Respondent }\end{array}$ & $\begin{array}{c}\text { Percentage } \\
(\mathbf{\%})\end{array}$ \\
\hline Extremely Cold & 0 & $0 \%$ \\
\hline Cold & 0 & $0 \%$ \\
\hline Comfortable & 10 & $16.67 \%$ \\
\hline Hot & 46 & $76.67 \%$ \\
\hline Extremely Hot & 4 & $6.66 \%$ \\
\hline Total & 60 & $100 \%$ \\
\hline
\end{tabular}

Table 3 provided data on residence satisfaction due to the surrounding temperature. Majority of them state the temperature is hot and only ten (10) of them rated as comfortable. From the observation at this area, there is fewer trees were planted within the compound, which could be one of the factors contributed to the less comfortable temperature in this area. Besides that, carbon dioxide emissions from burning gasoline for transportation is part of global warming cause which also affect the global temperature [6]. Thus, the transportation of lorry from the quarry mining area also contributes the impact to the resident area.

Table 4. Air Quality.

\begin{tabular}{|c|c|c|}
\hline Air Quality & No of Respondent & $\begin{array}{c}\text { Percentage } \\
(\mathbf{\%})\end{array}$ \\
\hline Extremely Dry & 14 & $23.33 \%$ \\
\hline Dry & 34 & $56.67 \%$ \\
\hline Comfortable & 12 & $20 \%$ \\
\hline Humid & 0 & $0 \%$ \\
\hline $\begin{array}{c}\text { Extremely } \\
\text { Humid }\end{array}$ & 0 & $0 \%$ \\
\hline Total & 60 & $100 \%$ \\
\hline
\end{tabular}

Air quality plays an important indicator to in evaluating the quality of air for human and its influence on their well-being. Table 4 stated that majority of the respondent (34) agreed that the air in this area is dry. In fact, 14 of them rated the air as extremely dry. This result shows the majority of the respondents were not satisfied with the quality of air in their residential.

One of the contributors to this issue decreasing air quality control is the transportation of the materials activities from the quarry mining site. The movement of vehicles produced dust. This lead to possibly stagnate the growth process and disability to maintain a balance between the volume of Oxygen and Carbon dioxide. Hence, hinder to the purification of the environment. Therefore, the level or air quality become worsens [6].

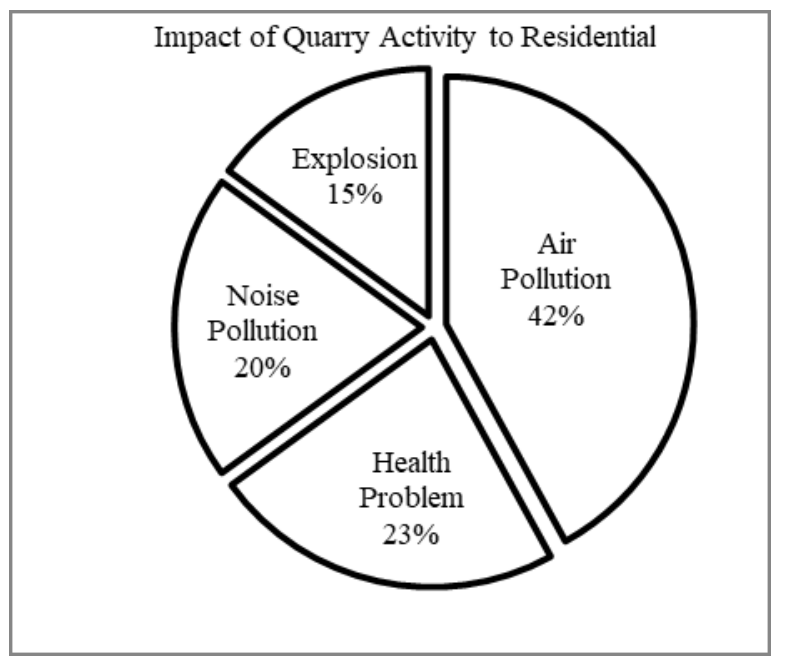

Fig. 1. The impact of quarry mining on residential.

Figure 1 shows the impact of quarry mining to residents. It can be concluded that the air pollution is most affected by the mining activities with gave impact $42 \%$ higher 
than the rest, then health problem $(23 \%)$ and followed by noise pollution $(20 \%)$. While the explosion $(15 \%)$ is the least affected by the quarry mining activities to their residential. According to Ibrahim (2010) [1], the operation of quarry not only produced dust to the residential nearby but also many complaints from the residents of other issues such as air pollution, the explosion and noise pollution. In line with this [7], also stated that air pollution is the main problem as operation technical failed to follow the guideline, for example, the conveyor used to prevent the dust spreading left uncovered.

Table 5. Residence perception on Quarry Activities.

\begin{tabular}{|l|l|l|l|}
\hline No & Question & Yes & No \\
\hline 1. & $\begin{array}{l}\text { Did residents have health problems due } \\
\text { to quarry activity? }\end{array}$ & 40 & 20 \\
\hline 2. & $\begin{array}{l}\text { Are your residential area affected by the } \\
\text { quarry activities? }\end{array}$ & 44 & 16 \\
\hline 3. & Did the DOE visited affect residential? & 46 & 14 \\
\hline 4. & $\begin{array}{l}\text { Could the DOE overcome the quarry } \\
\text { activities' problems? }\end{array}$ & 39 & 21 \\
\hline
\end{tabular}

This part is purposely to identify the perception of resident towards quarrying activities near their residential. Table 5 stated that 40 numbers of the respondents agree that quarry activities do impact their health. 44 of them also agree that residential area affected by the quarry activities. This might be caused by blasting activity and the number of lorries carrying quarry stone using the public route. Along with the dust, there are also having issues of noise and traffic congestion. Residents are also agreed despite there were visits done by DOE to witnesses the current environment condition at area there still lacking actions undertaken to improve the current condition.

In the last section, the respondent was asked about the preventive measure to be implemented in order to improve and reduce the impact of quarrying activities on their residential area. Preventive measures suggested are listed in table 5. Respondents agree that preventive measure can be successfully done by both, residents and authorities. However, it needs to be strategized to make everybody aware of the importance of protecting our environment. Action without proper study may lead to failure and waste of time, manpower and financial.

Table 6. Preventive Measure.

\begin{tabular}{|c|l|}
\hline No & \multicolumn{1}{|c|}{ Preventive Measures } \\
\hline 1 & $\begin{array}{l}\text { Spreading the information to the residents about } \\
\text { the negative impact of quarry mining and its } \\
\text { effect. }\end{array}$ \\
\hline 2 & $\begin{array}{l}\text { Local authority needs to prepare good } \\
\text { infrastructure to overcome air pollution in the } \\
\text { residential area. }\end{array}$ \\
\hline 3 & $\begin{array}{l}\text { Local authority needs to spread information on } \\
\text { the importance of keeping clean air to the } \\
\text { community. }\end{array}$ \\
\hline 4 & Enhance the agriculture activity around the \\
\hline
\end{tabular}

\begin{tabular}{|c|l|}
\hline & $\begin{array}{l}\text { residential area to filter the dust from nearby } \\
\text { quarrying activity }\end{array}$ \\
\hline 5 & $\begin{array}{l}\text { Enhancement by using an air filter to keep the air } \\
\text { clean }\end{array}$ \\
\hline 6 & $\begin{array}{l}\text { Enhance air quality by increasing the dust filter } \\
\text { around quarry mining }\end{array}$ \\
\hline 7 & $\begin{array}{l}\text { Improve the safety act in housing construction } \\
\text { near the quarry mining area }\end{array}$ \\
\hline 8 & $\begin{array}{l}\text { Quarry organization need to ensure the activity of } \\
\text { quarry follow Environmental Impact Assessment } \\
\text { (EIA) have been prepared by the Department of } \\
\text { Environment (DOE) }\end{array}$ \\
\hline 9 & $\begin{array}{l}\text { The developer should take any initiative to } \\
\text { control the environmental problems in the } \\
\text { vicinity of residential especially near the quarry } \\
\text { mining area }\end{array}$ \\
\hline
\end{tabular}

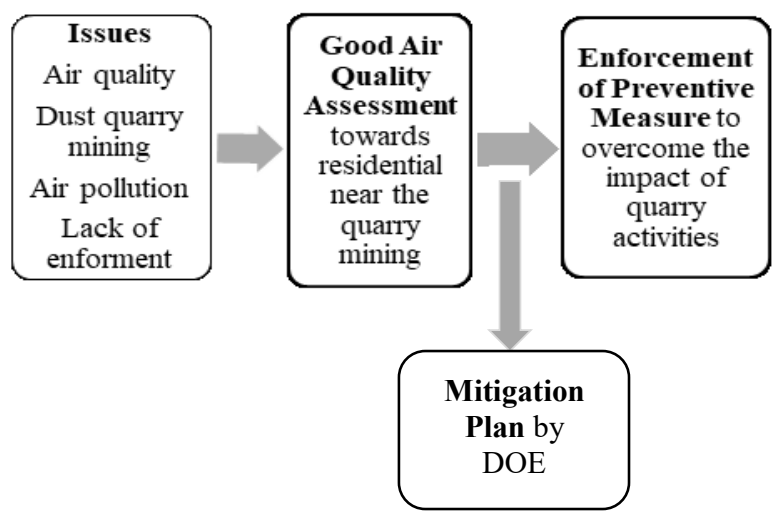

Figure 2: Key factors in Quarrying Activities

As illustrated in Figure 2, it can be concluded that the issues on air quality, dust quarry mining, air pollution and lack of enforcement factors are influencing the ineffectiveness of preventive measure provided by Department of Environment (DOE). Hence, there is a need for DOE to take action to provide good air quality for residential near the quarry mining vicinity, with the cooperation of quarry management and developer in achieving a sustainable quarry environment. Preventive measure in Table 5 would be a new factor for DOE to be considered.

\section{Conclusions}

This study reveals that residents were highly affected by quarrying activities. There are affected by air quality, cleanliness and noise level. Besides, they are relying on local authority to play the role in this case, residents could also start in strategizing how to reduce the impact such as planting more trees at their housing area and using an air purifier. However, local authorities including DOE also need to revise and take action immediately to improve the environmental impact in this area. This study is anticipated to benefit the residents near quarry mining vicinity as well as authorities to further investigate the real situation and providing the solution to improve the impact. 
The authors would like to extend their greatest appreciation to all participants for giving their valuable time, cooperation and support. The authors also acknowledge the Grant Bestari Perdana 600-IRMI/DANA 5/3/BESTARI(P)(089/2018) to give funding and support of this research.

\section{References}

1. Ibrahim, W. Z. (2010). Towards Sustainable Quarry Industry in Malaysia. Malaysia, JURUTERA.

2. Ng, S. K. W. (2012). A Study of the Air Pollution Index Reporting System, (June), 1-51.

3. Ministry of Natural Resources and Evironment, " Act Section 34A, Environmental Quality Act", (1974)

4. Wahid, R. (2010). Input Ekologi dalam Penilaian Impak Alam Sekitar (EIA) bagi Langkah. Malaysian Journal of Environmental Management, 45-56.

5. Mineral and Geoscience Department of Malaysia. (2013). Retrieved November 232013 from Laman Web Rasmi Jabatan Mineral dan Geosains Malaysia : http://www.jmg.gov.my/

6. Lameed. (2010). Effect of quarrying activity on biodiversity: Case study. African Journal of Environmental Science and Technology, 740-750.

7. Tarmizi, N. I. (2014). Towards a Sustainable Quarry Industry In Malaysia. Penambahbaikan Garis Panduan dalam Prosedur Penyerahan Lombong Kuari bagi Jabatan Teknikal, 123-12 